\title{
Assessing Effectiveness of Climate Smart Activities: A Study from Rural Areas, Nepal
}

\author{
Sarina Khanal ${ }^{1}$, Ram Asheshwar Mandal ${ }^{2 *}$ and Abhishesh Nepal ${ }^{1}$ \\ ${ }^{1}$ College of Applied Science, Nepal \\ ${ }^{2}$ School of Environmental Science and Management, Nepal
}

Submission: February 06, 2019, Published: February 19, 2019

*Corresponding author: Ram Asheshwar Mandal, School of Environmental Science and Management, Kathmandu, Nepal

\begin{abstract}
This study was objectively carried out to assess the trend of temperature and rainfall, evaluate the effectiveness of Climate Smart Activities, find the impact of climate change on resources and explore the climate smart policies and practices. The study was carried out in three piloted and three non-piloted rural municipality from Siraha, Gorkha and Kaski districts. Temperature and rainfall data for forty years of these districts were collected from Department of Hydrology and Meteorology [1]. The household survey, focus group discussion, key informant interview and field observation were carried out to collect data. The climate smart policies and practices were also collected. In Gorkha, the highest precipitation was observed in 1995 i.e. $4063.9 \mathrm{~mm}$ while lowest precipitation was only $1418 \mathrm{~mm}$ in 1969. The highest minimum and maximum temperature was observed in 1969,1970 and 2000 i.e. $25^{\circ} \mathrm{C}$ and lowest was observed in 1979 and 2001 with $9{ }^{\circ} \mathrm{C}$. The climate change impacts like crop calendar changed and increment in several diseases and pest in flora and fauna are observed. The water sources have been drying and irregular. In Gakhu rural municipality (RM)-6, the $100 \%$ people has adopted knowledge smart practices whereas $96.67 \%$ energy, carbon smart practices, $93.33 \%$ water smart practices, 70\% agriculture smart practices and 60\% biodiversity smart practices. In Dhangadimai-13 RM of Siraha, 89.99\% people has adopted water smart practices. Likewise, in Rupa-2 RM of Kaski, $61.29 \%$ people has adopted carbon and energy smart practices. MannKendel test tau b showed that the significant differences in temperature and rainfall trend. Krusker- Wallis test shows that there were significant differences of performance of adaptation program among RMs because $p$ value is less than 0.05 . The people of In Gakhu RM, the practices climate smart activities like 3 rooftop water harvesting, 46 water tanks, 1 water resource conservation and 40 improved cattle house, 5 drip irrigation, 27 plastic tunnel and 57 improved cooking stoves. This research will be useful to adopt the climate smart practices in other areas too.
\end{abstract}

Keywords: Climate smart village; Climate smart practices; Temperature; Rainfall

Abbreviations: CSV: Climate Smart Villages; RM: Rural Municipalities; DoEnv: Department of Environment; NAPA: National Adaptation Plan of Action; DHM: Department of Hydrology and Meteorology

\section{Introduction}

Adaptation practices are action that are taken to help communities and ecosystems to cope with changing climate condition [2,3]. The climate change impacts are expected to be particularly severe in the developing world and among marginalized communities because of limited adaptive capacity $[4,5]$. Climate Smart Villages (CSV) are sites where researchers from national and international organizations, farmers cooperatives, local government leaders, private sector organizations and key policy planners come together to identify which climate-smart agriculture interventions are most appropriate to tackle the climate and agriculture challenges in the village $[6,7]$.

Climate Smart Village was first implemented in Kavre District in Nepal by International Centre for Integrated Mountain Development [8] in 2015 with 6 different interventions namely Nutrient, Water, Crop, Future, ICT and Energy Smart Practices. More Climate Smart Village has been implemented in Nawalparasi, Kaski and Lamjung in 2015-16. In 2017, Department of Environment (DoEnv) has implemented Climate Smart Village in 13 districts which has five different interventions: water, Agricultural, Carbon and Energy, Biodiversity and Knowledge Smart Practices.

This research was done for assessing the effectiveness of the CSV program launched by Department of Environment (DoEnv) in three different rural municipalities (RM) of three different districts: Rupa RM Kaski, Gakhu RM Gorkha and Dhangadimai RM Siraha. These districts were selected according vulnerability index as mentioned by NAPA report, $2010[9,10]$. Out of which two districts Siraha and Gorkha are highly climate vulnerable and one Kaski is moderately climate vulnerable. The research was oriented on assessing the effect of climate change in different sectors and their adaptation practices on those districts. Climatic (temperature and rainfall) data from hydro meteorological stations nearer to project location has been brought for analyzing 
different trends of different time and seasons. This research was objectively carried out to show the trend of temperature and rainfall, evaluate the effectiveness of Climate Smart Activities at Rupa, Gakhu and Dhangadimai RM, assess the impact of climate change on resources and explore the climate smart policies and related practices.

\section{Materials and Methods}

\section{Study area}

Among the 13 rural municipalities (RM) implemented by Department of Environment (DoEnv), three RM namely Rupa-2 of Kaski, Gakhu- 6 of Gorkha and Dhangadimai-13 of Siraha District were selected for the study. These RMs was selected according to the vulnerability ranking of NAPA (National adaptation plan of action) reports 2010. Simultaneously these RM's represent the different climatic zones too. Dhangadimai-13 as Tropical Climate Zone, Rupa-2 and Gakhu-6 as Sub-Tropical Climate Zone respectively. From these RM's, villages having climate smart program were selected as a study site.

Siraha District lies in an altitude of $80 \mathrm{~m}$ (260ft) from sea level which has tropical climate zone and has latitude of $26^{\circ} 38^{\prime} 23.07^{\prime \prime} \mathrm{N}$ and longitude of $86^{\circ} 11^{\prime} 7.25^{\prime \prime}$ with elevation of $300-1000 \mathrm{~m}$ respectively. Nirmal Agricultural Group was selected as a registered climate smart applier under DoEnv. According to NAPA document 2010 Siraha was ranked as high $(0.601-0.786)$ to an overall climate vulnerability index (Figure 1).

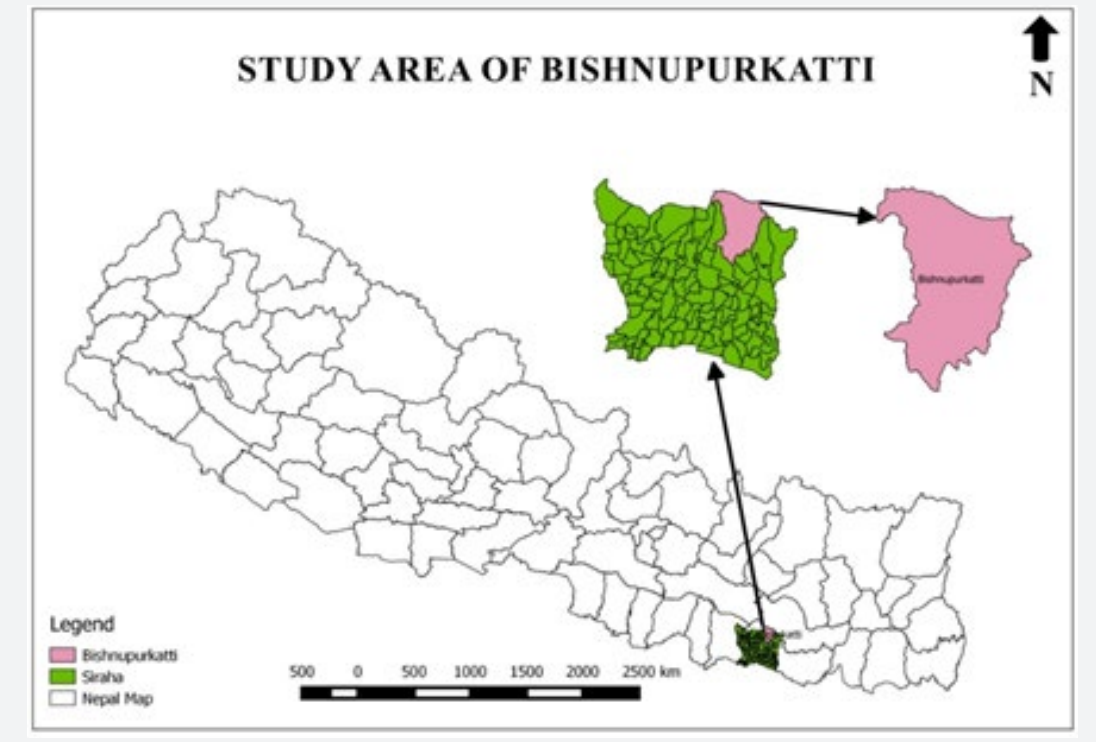

Figure 1: Map of Bishnupurkatti.

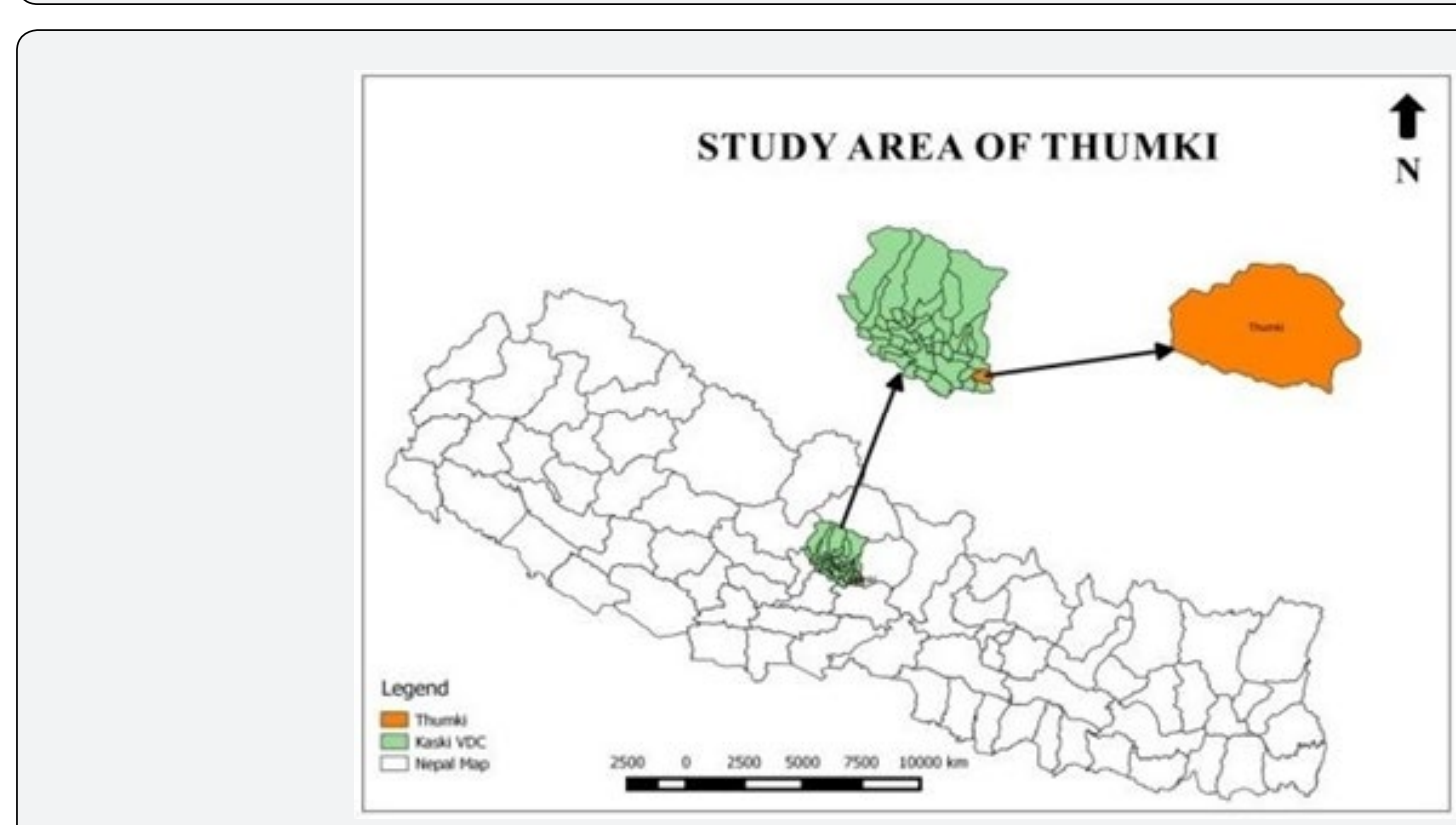

Figure 2: Map of THUMKI, Kaski. 
Kaski District lies in an altitude of $750 \mathrm{~m}$ (2460.63ft) from sea level which has Sub-tropical climate zone and has latitude of $28^{\circ} 16^{\prime} 0.8^{\prime \prime} \mathrm{N}$ \& longitude of $83^{\circ} 58^{\prime} 6.64^{\prime \prime}$ with elevation of 450-8091m respectively. Shree Jagriti Agricultural and Animal Husbandry Group was selected as registered climate smart applier under DoEnv. According to NAPA document 2010 Kaski was ranked as moderate $(0.356-0.600)$ to an overall climate vulnerability index (Figure 2).
Gorkha District lies in an altitude of 1106m (3628.609ft) from sea level which has Sub-tropical climate zone and has latitude of $28^{\circ} 3^{\prime} .372^{\prime \prime} \mathrm{N}$ and longitude of $84^{\circ} 37^{\prime} .432^{\prime \prime} \mathrm{E}$ with elevation of 488$8166 \mathrm{~m}$ respectively. Shree Hanumaan Multipurpose Agricultural was selected as a registered climate smart applier under DoEnv. According to NAPA document 2010 Gorkha was ranked as high (0.601-0.786) to an overall climate vulnerability index (Figure 3).

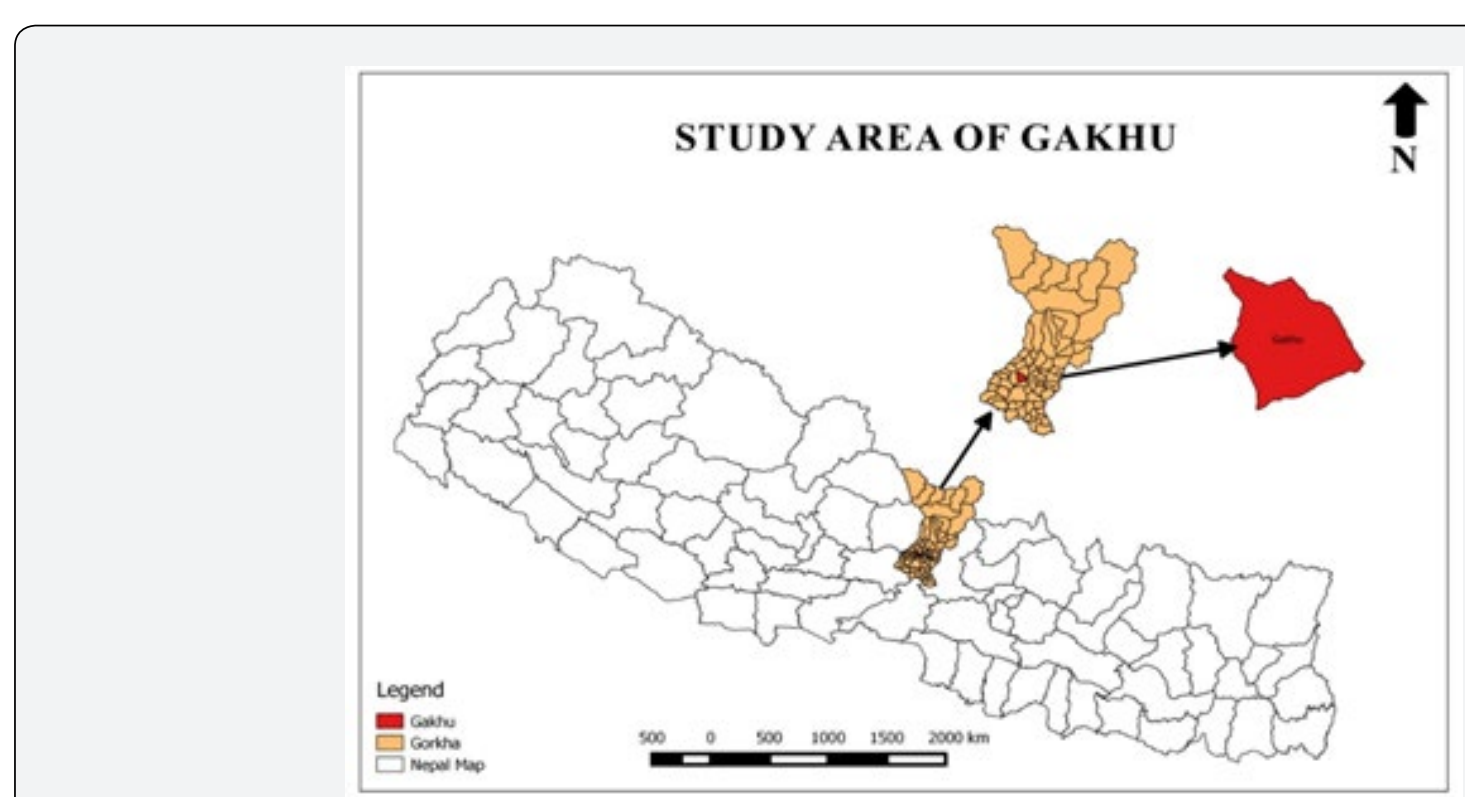

Figure 3: Map of GAKHU.

House hold survey- The household questionnaire was prepared and conducted for 180 households with 60 in each study site. Altogether 3 FGD was conducted, One FGD in each study area while altogether 15 KII was conducted 5 from each RM. In addition, Climatic data of nearest meteorological station published by Department of Hydrology and Meteorology (DHM) was collected and analyzed. The data published by Central bureau of Statistics, Results and Discussion

\section{Trend of temperature and rainfall at Kaski, Gorkha and Siraha}

Table 1: Temperature and Rainfall Data of Study Area.

\begin{tabular}{|c|c|c|c|}
\hline \multirow{2}{*}{ Parameters } & \multicolumn{3}{|c|}{ Study area } \\
\hline & Rupa (Kaski) & Gakhu (Gorkha) & Dhangadimai (Siraha) \\
\hline Maximum Annual Rainfall & $4879 \mathrm{~mm}$ & $1362.1 \mathrm{~mm}$ & $2331.9 \mathrm{~mm}$ \\
\hline Minimum Annual Rainfall & $2050 \mathrm{~mm}$ & $728.1 \mathrm{~mm}$ & $735 \mathrm{~mm}$ \\
\hline Mann- Kendall's tau-b test for annual rainfall & 0.281 & 0.055 & 0.213 \\
\hline Maximum Post Rainfall & $508.8 \mathrm{~mm}$ & $274 \mathrm{~mm}$ & $428.5 \mathrm{~mm}$ \\
\hline Minimum Post Rainfall & $38.1 \mathrm{~mm}$ & $0 \mathrm{~mm}$ & $0 \mathrm{~mm}$ \\
\hline Mann- Kendall's tau-b test for Post rainfall & 0.47 & 0.177 & 0.967 \\
\hline Maximum Pre-Rainfall & $920.3 \mathrm{~mm}$ & $435.7 \mathrm{~mm}$ & $426.6 \mathrm{~mm}$ \\
\hline Maximum Pre-Rainfall & $0 \mathrm{~mm}$ & $82.2 \mathrm{~mm}$ & $25.4 \mathrm{~mm}$ \\
\hline Mann- Kendall's tau-b test for Pre-Rainfall & 0.184 & 0.933 & 0.003 \\
\hline Maximum Monsoon Rainfall & $4063.9 \mathrm{~mm}$ & $3406.5 \mathrm{~mm}$ & $2059.9 \mathrm{~mm}$ \\
\hline Minimum Monsoon Rainfall & $1418 \mathrm{~mm}$ & $587.3 \mathrm{~mm}$ & $530.8 \mathrm{~mm}$ \\
\hline
\end{tabular}




\section{Agricultural Research \& Technology: Open Access Journal}

\begin{tabular}{|c|c|c|c|}
\hline Mann- Kendall's tau-b Test Monsoon Rainfall & 0.233 & 0.09 & 0.457 \\
\hline Highest Maximum Temperature & $25{ }^{\circ} \mathrm{C}$ & $25.3{ }^{\circ} \mathrm{C}$ & $33{ }^{\circ} \mathrm{C}$ \\
\hline Lowest Maximum Temperature & $23.1{ }^{\circ} \mathrm{C}$ & $9.5{ }^{\circ} \mathrm{C}$ & $19.3{ }^{\circ} \mathrm{C}$ \\
\hline Mann- Kendall's tau-b Test for Maximum Temperature & 0.658 & 0.004 & 0.022 \\
\hline Highest Minimum Temperature & $18 . \stackrel{\circ}{\circ} \mathrm{C}^{\circ}$ & $16.8{ }^{\circ} \mathrm{C}$ & $21.5{ }^{\circ} \mathrm{C}$ \\
\hline Lowest Minimum Temperature & $11{ }^{\circ} \mathrm{C}$ & $9^{\circ} \mathrm{C}$ & $10.6{ }^{\circ} \mathrm{C}$ \\
\hline Mann- Kendall's tau-b Test for Minimum Temperature & 0.046 & 0 & 0.817 \\
\hline
\end{tabular}

The result shows that annual maximum and minimum temperature trend is increasing in Rupa and Gakhu while decreasing in Dhangadimai RM. The trend of total monsoon temperature was increasing in Rupa and Dhangadimai but it was decreasing in Gakhu. The altitude of Rupa and Gakhu are $886 \mathrm{~m}$ and $1106 \mathrm{~m}$ respectively, comparatively which lies in higher altitude than Dhangadimai showing increasing trend of the annual temperature. So, the study is quite similar the study done by Government of Nepal 2015 which shows the average trend of mean annual maximum temperature over Nepal is 0.06 ${ }^{\circ} \mathrm{C} / \mathrm{yr}$. Moreover, study conducted by Nayaju et al. [11] shows annual mean temperature of country is rising at the rate of 0.41 ${ }^{\circ} \mathrm{C}$ per decade. Dhangadimai lies in as lower altitude of $80 \mathrm{~m}$ which shows decreasing trend of annual minimum and maximum temperature. According to DHM [1], the magnitude of winter maximum temperature trend is negative or lowest positive in the southernmost districts (Tarai districts) and the magnitude increases towards north with elevation (Table 1).

The trend of annual rainfall pattern shows increasing which is similar to $10.673 \mathrm{~mm}$ per annum, studied done by Baidya et al. [12]. According to him, there was increasing trend in precipitation below $1500 \mathrm{~m}$ elevation, while it was decreasing trend above 1500m [13]. According to MoPE [10], the Gorkha district lies in drought prone area and the study of Gakhu shows decreasing trend of annual rainfall pattern.

\section{Effectiveness of climate smart activities in Rupa-2, Gakhu-6 and Dhangadimai-13 RM}

Table 2: Climate Smart Practices Adopted on Study Area.

\begin{tabular}{|c|c|c|c|c|}
\hline \multirow{2}{*}{ SN } & \multirow{2}{*}{$\begin{array}{c}\text { Climate Smart } \\
\text { Practices }\end{array}$} & \multicolumn{3}{|c|}{ Study Area } \\
\cline { 3 - 5 } & Rupa & Gakhu & Dhangadimai \\
\hline 1 & Water Smart Practices & $32.28 \%$ & $93.33 \%$ & $89.99 \%$ \\
\hline 2 & $\begin{array}{c}\text { Agriculture Smart } \\
\text { Practices }\end{array}$ & $51.61 \%$ & $70.00 \%$ & $60.00 \%$ \\
\hline 3 & $\begin{array}{c}\text { Energy \& Carbon Smart } \\
\text { Practices }\end{array}$ & $61.29 \%$ & $96.67 \%$ & $49.01 \%$ \\
\hline 4 & $\begin{array}{c}\text { Biodiversity Smart } \\
\text { Practices }\end{array}$ & $0.00 \%$ & $60.00 \%$ & $63.00 \%$ \\
\hline 5 & $\begin{array}{c}\text { Knowledge Smart } \\
\text { Practices }\end{array}$ & $0.00 \%$ & $100 \%$ & $76.67 \%$ \\
\hline
\end{tabular}

Effectiveness of climate smart practices was done in three RM Rupa, Gakhu and Dhangadimai of Kaski, Gorkha and Siraha District respectively (Table 2). The result shows that, the overall climate smart practices was the most benefited community in Gakhu, second in Dhangadimai and lowest in Rupa RM. According to MoPE
[10] document the Gorkha district was ranked in high vulnerability index due to erratic rainfall and rise in temperature which causing recurring natural disaster like flash flood, landslide, drought and increase in pest. The performance of Gakhu RM is higher, it might be due to implementation of climate smart practices, capable of coping with the changing climate and the community adopts new interventions [14]. It might be due to occasional events such as earthquake in Gorkha 2015 which cause massive destruction, from the event people were mostly affected in their livelihood and socio-economic condition. Affected community was always in search of such new implementation, meanwhile in this time the programme was implemented in the community and people were most willing to implement the program to cope with the situations in a sustainable way. The success study is similar to the Climate Smart Village in Haryana, India where climate smart agricultural practice was more focused such as ICT service to access weather, zero-tillage, laser land leveling, residual management, crop diversification, agro-forestry, precision nutrient management $[15,16]$.

Dhangadimai is second benefited community, in general expectation the people in the community lies in the medium index and their source of income is agriculture as a major occupation; these practices are familiar to adopt and cope with the extreme event. Though the crop farming is the mainstay of the people in Tarai, every household are involved in farming and raising livestock and the Climate Smart Village programme is very supportive to enhance the agricultural production, cope with water scarcity and safe guarding the natural resources as well as help in socioeconomic condition of the community. In occasional expectation it might be due to occasional events such as flood, Siraha is very prone to flood and drought and the event will severely affect the socio-economic condition of the community as well loss in agricultural production.

According to NAPA 2010 document, the areas of Kaski was ranked as moderate in vulnerability index [10]. The erratic rainfall and rise in temperature causing frequent natural disaster such as flash flood, landslide, earthquake and increase in pest in the agriculture are the common impact. After the devastating earthquake of 2015 has dried almost all the water sources which has lead, sever impact in settlement and in socio economic condition. This unhygienic settlement might lead to lower in performance in the community. The Knowledge Smart Practices and Biodiversity Smart Practices were not implemented in the community so that they do not have proper knowledge about the 
adaptation programme and how to implement it in a sustainable way. Due to simple, affordable and replicable technologies in Kavre District the pilot Climate Smart Village has develop 500 household reached nutrient smart, 100 reach ICT smart, 180 reach Future smart and 400 farmers reach water smart practices with the performance higher [8].

\section{Non- climate smart practices in Rupa-2, Gakhu-6 and Dhangadimai-13 RM}

The respondents of non- climate smart practice have been practicing water smart practice, agriculture smart practice, carbon and energy smart practice, biodiversity smart practice and knowledge smart practice. The result has been presented on the table below (Table 3).

Table 3: Non-Climate Smart Practices Adopted by Study Area.

\begin{tabular}{|c|c|c|c|c|}
\hline \multirow{2}{*}{ SN } & \multirow{2}{*}{$\begin{array}{c}\text { Non - Climate Smart } \\
\text { Practices }\end{array}$} & \multicolumn{3}{|c|}{ Study Area } \\
\cline { 3 - 5 } & Rupa & Gakhu & Dhangadimai \\
\hline 1 & Water Smart Practices & $23.33 \%$ & $16.67 \%$ & $0.00 \%$ \\
\hline 2 & $\begin{array}{c}\text { Agriculture Smart } \\
\text { Practices }\end{array}$ & $23.33 \%$ & $16.67 \%$ & $0.00 \%$ \\
\hline 3 & $\begin{array}{c}\text { Energy \& Carbon Smart } \\
\text { Practices }\end{array}$ & $60.00 \%$ & $36.67 \%$ & $20.00 \%$ \\
\hline 5 & $\begin{array}{c}\text { Biodiversity Smart } \\
\text { Practices }\end{array}$ & $36.67 \%$ & $36.67 \%$ & $0.00 \%$ \\
\hline 5 & $\begin{array}{c}\text { Knowledge Smart } \\
\text { Practices }\end{array}$ & $23.33 \%$ & $16.67 \%$ & $0.00 \%$ \\
\hline
\end{tabular}

Table 4: Non-Climate Smart Practices Adopted by Study Area.

\begin{tabular}{|c|c|c|c|c|c|c|}
\hline \multirow{2}{*}{ SN } & \multirow{2}{*}{ Name of Practices } & \multicolumn{3}{|c|}{ Mean Rank } & \multirow{2}{*}{ P-Value } & \multirow{2}{*}{ Decision } \\
\hline & & Gakhu & Rupa & Dhangadimai & & \\
\hline 1 & Climate Smart Practices & 62.78 & 26.38 & 47.33 & 0 & Significant Differences \\
\hline 2 & Non- Climate Smart Practices & 45.63 & 54.57 & 36.3 & 0.007 & Significant Differences \\
\hline 3 & Water Smart Practices & 64.5 & 35.33 & 55.67 & 0 & Significant Differences \\
\hline 4 & Non-Water Smart Practices & 47.08 & 49.42 & 40 & 0.2 & No Significant Differences \\
\hline 5 & Agricultural Smart Practices & 55.87 & 39.45 & 41.18 & 0.025 & No Significant Differences \\
\hline 6 & Non-Agricultural Smart Practices & 49 & 49 & 38.5 & 0.017 & No Significant Differences \\
\hline 7 & Carbon and Energy Smart Practices & 54 & 40.3 & 41.83 & 0.003 & Significant Differences \\
\hline 8 & Non-Carbon and Energy Smart Practices & 45 & 49.5 & 42 & 0.353 & No Significant Differences \\
\hline 9 & Biodiversity Smart Practices & 45.1 & 0 & 54.4 & 0.001 & Significant Differences \\
\hline 10 & Non-Biodiversity Smart Practices & 48 & 53.2 & 35.3 & 0.008 & Significant Differences \\
\hline 11 & Knowledge Smart Practices & 67 & 0 & 28 & 0 & Significant Differences \\
\hline 12 & Non-Knowledge Smart Practices & 47 & 50 & 39.5 & 0.025 & No Significant Differences \\
\hline
\end{tabular}

Impact of climate change on resources in Rupa-2, Gakhu-6 and Dhangadimai-13 RM

The increment or decrement in number of wild animals might be due to the lack of adaptation to the environment and its rising temperature. The rate of decreasing of indigenous species is very high as well emerging rate of invasive species was seen higher in Gakhu then in Rupa and in Dhangadimai. The extinction rate of flora and fauna was seen higher in all community $[17,18]$.
The performance was the higher in Rupa and much lower in Gakhu and Dhangadimai RM in non-climate smart village. Only $20 \%$ people were benefited in the community in Rupa from local organization, Red Cross and Environment friendly organization. In Dhangadimai, it was only $15 \%$ benefited community. Due to lack of proper adaptation programme and climate smart village implementation in all community the people are facing water scarcity, lower in agricultural yield, increase in pest and disease, more consumption of fuel wood and improper cattle dung which cause increase in the epidemics also people are unaware of the changing climate and how to cope with it.

\section{Statistical comparison of climate smart practices}

The Kruskal-Wallis test shows that there was no significant difference for $\mathrm{p}$-value higher than 0.05 and significant difference for p-value less than 0.05 for the performance of adaptation program among RM's. The result has been presented on the table below (Table 4).

\section{Comparison between climate smart and non-climate practices}

The Mann Whitney test showed that there was significance differences in climate smart practices, water smart practices, agriculture and energy practice between inside the pilot and outside pilot area. However, some practices were not significance difference. More detail is the in Table 5.
Some of forest plants are dying due to several diseases. There was increasing number of pest, insects and disease such as Anthracnose fungus in mango and yellowing in Sissoo by microfungal Polyporaceae, ant, caterpillar, scorpion, centipedes in forest.

There was change in flowering or blooming period of the majority of vegetables, fruits or an agronomical crops. The flowering and blooming period has been shifted by one month earlier in Dhangadimai and fifteen days earlier in Gakhu and Rupa 
RM. The overall respondent has noticed that decline in the seed quality. The present seeds are smaller in size as well as tasteless in comparison to past. Increasing number of pests such as Alternaria alternata fungus in potato, Panama wilt in banana, Anthracnose fungus in tomato, Caterpillar in cabbage and cauliflower, Anthracnose fungus in tomato, Mosaic in papaya and Vine Red Table 5: Mann Whitney Test among Climate Smart and Non-Climate Practices in 3 RM's.

\begin{tabular}{|c|c|c|c|c|}
\hline \multirow{2}{*}{ SN } & \multirow{2}{*}{ Practices } & \multicolumn{3}{|c|}{ Mann Whitney Test } \\
\hline & & $\mathbf{R M}$ & P-Value & Decision \\
\hline \multirow{3}{*}{1} & \multirow{3}{*}{ Climate Smart Practices } & Rupa & 0 & Significant Differences \\
\hline & & Gakhu & 0 & Significant Differences \\
\hline & & Dhangadimai & 0 & Significant Differences \\
\hline \multirow{3}{*}{2} & \multirow{3}{*}{ Water Smart Practices } & Rupa & 0 & Significant Differences \\
\hline & & Gakhu & 0 & Significant Differences \\
\hline & & Dhangadimai & 0 & Significant Differences \\
\hline \multirow{3}{*}{3} & \multirow{3}{*}{ Agriculture Smart Practices } & Rupa & 0 & Significant Differences \\
\hline & & Gakhu & 0 & Significant Differences \\
\hline & & Dhangadimai & 0 & Significant Differences \\
\hline \multirow{3}{*}{4} & \multirow{3}{*}{ Carbon \& Energy Smart Practices } & Rupa & 0.391 & No Significant Differences \\
\hline & & Gakhu & 0.296 & No Significant Differences \\
\hline & & Dhangadimai & 0.109 & No Significant Differences \\
\hline \multirow{3}{*}{5} & \multirow{3}{*}{ Biodiversity Smart Practices } & Rupa & 0.05 & No Significant Differences \\
\hline & & Gakhu & 0 & Significant Differences \\
\hline & & Dhangadimai & 0.236 & No Significant Differences \\
\hline \multirow{3}{*}{6} & \multirow{3}{*}{ Knowledge Smart Practices } & Rupa & 0 & Significant Differences \\
\hline & & Gakhu & 0.005 & No Significant Differences \\
\hline & & Dhangadimai & 0 & Significant Differences \\
\hline
\end{tabular}

Dixit et al. [19] and Agrawal et al. [20] reported that most of the people experienced that unavailability of water for irrigation and unfavorable distribution of rainfall and increasing temperature were the key factors for the decreasing in the amount of crop yield. Higher temperatures and droughts will reduce agricultural productivity. More than $80 \%$ farmers felt the occurrence of pests and weed has increase in agricultural production with unknown species of pest and insects including weeds like Raunde, Bande, Chinijhar (Scoparia dulcis), Bikashe, Chitlange, Banmara (Eupatorium odoratum), Aankhlejhar (Equisetum debile). Also, the increase in insect population leads to demand for more use of pesticides, which unknowingly may cause lots of harm to ecosystem as well as human society. Incidence of pest and diseases would be most severe in tropical region due to climate change and which is gradually shifting to the hills and mountains. According to IPCC's Fourth Assessment Report, $1{ }^{\circ} \mathrm{C}$ to $3{ }^{\circ} \mathrm{C}$ global man temperature increased by 2100 (relative to the 1990-2000 average level). This may lead to productivity decreases for some cereals in low latitudes, and productivity increases in high latitudes with the increase in the temperature and change in rainfall pattern, people have experienced new crop diseases, pest, and weeds.

According to the survey from the study area, majority of respondent has experience in decreasing level of water resources disease in pointed gourd were found in the study area. Similarly, all respondent has cultivated different crops such as tomato, black eyes bean, brinjal, yard long beans, pointed gourd and hybrid of tomato, string beans, radish, cauliflower, broccoli and hybrid of grains and maize in agricultural crops. as well as water resources has polluted due to low rainfall, diversion, high temperature, more water consumption and deforestation. Majority of respondent has managed water scarcity by storage, rainwater harvesting and by efficient use of water to cope with this water problem. According to IPCC projection, by the 2050 s, the area of land subject to increasing water stress due to climate change will be more than double that will decrease water stress. Increase in the drought period and decrease in rainfall had caused problem to the people as they need to spend their much time in fetching the water in past years. Almost 95\% sources were dried out in the three RM and some are still in phase of drying out. This situation causes more water stressed. Also due to Earthquake 2015 and upgrading road construction has cause change in the diversion of water channel which cause more sever in water problem in the community. In order to adapt with climate change impact, villagers have made arrangement of plastic ponds, rainwater harvesting, water tank for storage, power drill and water source conservation for irrigation and livestock with the support of DoEnv and Local organization.

In order to adapt with the climate change impact, villagers had made arrangement of plastic ponds, rainwater harvesting, water tank for storage, power drill and water source conservation for irrigation and livestock with the support of DoEnv and Local 
organization. Majority of respondent has adopted cooking and lighting practice such as fuel wood, LPG, electricity, improved cooking stove, bio-gas and solar for cooking and lighting practices in the community. Increment in the fuel wood consumption of the rural people lead to deforestation and in long-term basis cause drought in that area. To cope with the impact of changing climate in

Table 6: Krusker-Wallis Test in Resources in Rupa, Gakhu and Dhangadimai.

\begin{tabular}{|c|c|c|c|}
\hline SN & Resources & P-value & Decision \\
\hline \multirow{5}{*}{1} & \multicolumn{3}{|c|}{ Biodiversity Sector } \\
\hline & Perception of wild animals & 0 & Significant difference \\
\hline & Incoming of endangered, rare species & 0.283 & No significant difference \\
\hline & Observe any invasive species & 0.108 & No significant difference \\
\hline & Extinction rate of flora fauna & 0.001 & Significant difference \\
\hline \multirow{4}{*}{2} & \multicolumn{3}{|l|}{ Forest Sector } \\
\hline & Increasing no. of pest & 0.105 & No significant difference \\
\hline & Frequency of forest fire & 0.002 & Significant difference \\
\hline & Growth rate of tree species & 0.091 & No significant difference \\
\hline \multirow{4}{*}{3} & \multicolumn{3}{|c|}{ Agricultural Sector } \\
\hline & Change in flowering time & 0 & Significant difference \\
\hline & Change in seed quality & 0.001 & Significant difference \\
\hline & Cultivate different crops & 0.003 & Significant difference \\
\hline \multirow{4}{*}{4} & \multicolumn{3}{|c|}{ Water Sector } \\
\hline & Main source of water & 0 & Significant difference \\
\hline & Change in water resources & 0 & Significant difference \\
\hline & Manage to cope with water problem & 0 & Significant difference \\
\hline \multirow{3}{*}{5} & \multicolumn{3}{|c|}{ Energy Sector } \\
\hline & Cooking and lighting practices & 0 & Significant difference \\
\hline & Advantage of new technology & 0.003 & Significant difference \\
\hline
\end{tabular}

The respondents in the Rupa, Gakhu and Dhangadimai RM were observed to have adopted different practices to cope with impacts of climate change. DoEnv has implemented Climate Smart Programs with monitoring activities and with the help of local communities by preparing community-based strategies to make

community sustainable environmentally and socio-economically. Statistical comparison of impacts of climate change on different resources. The calculation was done in three different RMs, Rupa, Gakhu and Dhangadimai. The result has been presented on the Table 6 below.

\section{Policies and practices related to climate smart program at Rupa-2, Gakhu-6 and Dhangadimai-13 RM}

Table 7: Polices and practices in Climate Smart Villages.

\begin{tabular}{|c|c|c|c|c|c|c|c|}
\hline \multirow{2}{*}{ SN } & \multirow{2}{*}{ List of Practices } & \multicolumn{2}{|c|}{ Rupa } & \multicolumn{2}{|c|}{ Gakhu } & \multicolumn{2}{|c|}{ Dhangadimai } \\
\hline & & Policies & Practices & Policies & Practices & Policies & Practices \\
\hline 1 & Rooftop Water Harvesting & 74 & 24 & 3 & 0 & 0 & 0 \\
\hline 2 & Plastic Pond & 3 & 1 & 0 & 0 & 0 & 0 \\
\hline 3 & Water Tank & 12 & 3 & 46 & 43 & 51 & 49 \\
\hline 4 & Water Resource Conservation & 0 & 0 & 1 & 1 & 0 & 0 \\
\hline 5 & Improved Cattle House & 166 & 108 & 40 & 23 & 34 & 20 \\
\hline 6 & Drip Irrigation & 19 & 6 & 5 & 2 & 51 & 32 \\
\hline 7 & Plastic Tunnel & 57 & 23 & 27 & 19 & 19 & 10 \\
\hline 8 & Drought Resistant Crop & 0 & 0 & 1 & 1 & 1 & 0 \\
\hline 9 & Bio-Pesticide & 0 & 0 & 3 & 1 & 1 & 0 \\
\hline 10 & Vermin-composting & 0 & 0 & 4 & 1 & 0 & 0 \\
\hline 11 & Improved Cooking Stove & 61 & 38 & 57 & 55 & 51 & 25 \\
\hline
\end{tabular}




\section{Agricultural Research \& Technology: Open Access Journal}

\begin{tabular}{|l|c|c|c|c|c|c|c|}
\hline 12 & Plantation & 0 & 0 & 0 & 0 & 1 & 0 \\
\hline 13 & Solar Pump & 0 & 0 & 0 & 0 & 3 \\
\hline 14 & Home Herbal Garden & 0 & 0 & 0 & 0 & 1 \\
\hline 15 & $\begin{array}{c}\text { Master Nursery for Plant } \\
\text { Production }\end{array}$ & 0 & 0 & 1 & 1 & 1 \\
\hline 16 & Capacity Enhancement & 0 & 0 & 1 & 1 & 1 & 1 \\
\hline 17 & Community Seed Bank & 0 & 0 & 1 & 1 & 1 \\
\hline
\end{tabular}

According to the Climate Smart Village Working Schedule 2016, these three RM's were selected according to the NAPA 2010 report vulnerability index and LAPA report to cope with the changing climate by reduce its impacts and increasing the adaptive capacity of affected community. The result from the study area of the gap between the policies and practices of climate smart programme presented in the table below (Table 7). Similar policies have been developed and applied in other countries as well $[23,24]$.

\section{Conclusion and Recommendation}

The present study attempted to know the effectiveness of climate smart activities including climate change impact on resources with trend analysis of temperature and rainfall of Rupa (Kaski), Gakhu (Gorkha) and Dhangadimai (Siraha) RM of Nepal. From the people's perception and field observation the effectiveness was performed higher in Gakhu, medium in Dhangadimai and lowers in Rupa in climate smart village and in non-climate smart practices Rupa performs higher in the practices. Impact of climate change on different resources raise different issues and communities are already facing different problems due to the impacts of climate change such as decrease in agricultural production, loss in biodiversity, dry spell, drying of water resources, more consumption of fuel wood cause increase in GHG emission and infestation by new variety of pests and weeds. Among climate smart practices; water smart practices and agricultural smart practices were seen more fruitful to the community. For adaptation measures all practices of climate smart village should be implemented in the community and should be upgraded. Climate Smart Village Program should be need based rather than demand based.

\section{References}

1. DHM (2017) Observed Climate Trend Analysis in the RMs and Physiographic Regions of Nepal (1971-2014). Department of Hydrology and Meteorology, Kathmandu, Nepal, pp. 101.

2. UNFCCC (1992) The United Nations Framework Convention on Climate Change. United Nations Treaty Collection. pp. 197.

3. DRMP (2011) Disaster Risk Management Plan for Dhangadimai RM, Climate Change Adaptation and Disaster Risk Management in Agriculture. Ministry of Agriculture and Cooperatives Government of Nepal.

4. UNFCCC (2010) Glossary of Climate Change Acronyms.

5. IPCC (2014) Adaptation planning and implementation. In: Field CB, Barros VR, et al. (Eds.), Climate Change 2014: Impacts, Adaptation, and Vulnerability. Part A: Global and Sectoral Aspects. Contribution of Working Group II to the Fifth Assessment Report of the Intergovernmental Panel on Climate Change. Cambridge University Press, Cambridge, United Kingdom and New York, USA.
6. ICRAF (2011) World Agro-forestry Center; New Climate Smart Village for the Philippines.

7. Cruz AC, Navarro R, Tabing L (2016) Climate change reporting for rural broadcasters: engaging rural media for community mobilization on climate-smart agriculture in the Philippines. CCAFS Working Paper No. 177, CGIAR, Copenhagen, Denmark.

8. ICIMOD (2015) Climate Smart Villages Building Affordable and Replicable Adaptation Pilots in Mountain Areas.

9. Sagun (2009) Climate Change Impacts on Livelihoods of Poor and Vulnerable Communities and Biodiversity. A Case Study in Banke, Bardia, Dhading and Rasuwa Districts of Nepal. Strengthened Actions for Governance in Utilization of Natural Resources Project, Care Nepal, Kathmandu, Nepal, p. 56

10. MoPE (2010) National Adaptation Programme of Action to Climate Change. Ministry of Environment, Kathmandu, Nepal.

11. Nayaju RP, Jha PK, Sherchan K, Sharma DKP (2004) Initial National Communication Conference of the Parties of the United Nations Framework, Convention on Climate change. In: Kuwar P, Dahal G (Eds.), Ministry of Population and Environment, UNEP, Kathmandu, Nepal.

12. Baidya SK, Shrestha ML, Seikh MM (2008) Trends in daily temperature and precipitation in Nepal. Journal of Hydrology and Meteorology 5(1): 38.

13. Shrestha AB, Wake CP, Mayewski PA, Dibb JE (1999) Maximum Temperature Trends in the Himalaya and its Vicinity: An Analysis Based on Temperature Records from Nepal for the Period 1971-94. Journal of Climate.

14. Klein RJT, Smith JB (2003) Enhancing the capacity of developing countries to adapt to climate change: a policy relevant research agenda. Climate Change, Adaptive Capacity and Development. Imperial College Press, London, UK.

15. CIMMYT-CCAFS (2014) South Asia Coordinator International Maize and Wheat Improvement Centre (CIMMYT). India Office, CG Block, NASC Complex, Pusa, New Delhi, India.

16. Malla G (2008) Climate Change and its Impact in Nepalese Agriculture. The Journal of Agriculture and Environment 9: 62-71.

17. Kumar AS Walker, Molur S (2000) Prioritization of Endangered Species. Setting Biodiversity Conservation Priorities for India. New Delhi, India, p. 11

18. Barnekow Lilles $\varnothing$ JP, Shrestha TB, Dhakal LP, Nayaju RP, Shrestha R (2005) The map of potential vegetation of Nepal: a forestry/agro-ecological/biodiversity classification system. Development and Environment.

19. Dixit A, Subedi Y, Mcmahon T, Moench M (2013) Mainstreaming Climate Sensitive Indicators into an Existing Food Monitoring System: Climate Change and Food Security in Nepal. Kathmandu, Institute for Social and Environmental Transition-Nepal (ISET-Nepal).

20. Aggarwal P, Zougmore R, Kinyangi J (2013) Climate-Smart Villages: A community approach to sustainable agricultural development. Copenhagen, Denmark: CGIAR Research Program on Climate Change, Agriculture and Food Security (CCAFS). 
21. Foerch W, Sijmons K, Mutie I, Kiplimo J, Cramer L, et al. (2013) Core sites in the CCAFS regions: East Africa, West Africa and South Asia, Version 3. CGIAR Research Program on Climate Change, Agriculture and Food Security (CCAFS), Copenhagen, Denmark.

22. Ojango JM, Audho JO, Oyieng E, Recha J, Muigai A (2015) Sustainable small ruminant breeding program for Climate Smart Villages in Kenya. CCAFS Working Paper no. 127. CGIAR Research Program on Climate Change, Agriculture and Food Security CCAFS, Copenhagen, Denmark.
23. Aggarwal P, Zougmore R, Kinyangi J (2013) Climate-Smart Villages: A community approach to sustainable agricultural development. Copenhagen, Denmark: CGIAR Research Program on Climate Change, Agriculture and Food Security (CCAFS).

24. MoPE (2012) Mountain Environment and Climate Change in Nepal: National Report prepared for the International Conference of Mountain Countries on Climate Change. Ministry of Environment, Kathmandu, Nepal.

Your next submission with Juniper Publishers
will reach you the below assets
- Quality Editorial service
- Swift Peer Review
- Reprints availability
- E-prints Service
- Manuscript Podcast for convenient understanding
- Global attainment for your research
- Manuscript accessibility in different formats
( Pdf, E-pub, Full Text, Audio)
- Unceasing customer service
Track the below URL for one-step submission
https://juniperpublishers.com/online-submission.php

